\title{
A man of the theatre
}

\section{All the world's a stage.}

\section{Norman Spinrad}

I've been a man of the theatre for over a century. Old enough to have played Hamlet, and Richard, and any number of Henries, and Lear before my first rejuvenation and all in my own flesh and on the stage, not as an avatar, licensed or otherwise.

You remember the theatre, don't you?

Of course you don't. There hasn't been a play produced in what, a quarter of a century. In what I call a play, the characters must be played by live actors, not software emulations of the dead greats of yesteryear, who never played the parts themselves - and certainly not by one of myself.

And not because I could not compete with these pathetic avatars. Most of the roles in realies are played by the greats of the past, but because they all died before fleshware downloading technology was available, they've all been synthesized from old footage by the entertainment conglomerates that owned the rights, and they walk mechanically through the roles like the virtual robots they are, not even the virtual ghosts of true thespians.

What is more, I was offered an emulation contract many long years ago, which I scornfully turned down. Yes, I was that good. Good enough that they were willing to pay me royalties for the use of my avatar, even though they had a free casting call from over a century of film and television. But I would not betray the theatre for any amount of money.

The theatre, they declare, is obsolete. Why would anyone pay money to watch third-rate human actors staggering around on a platform in front of a flat painted set when they can tap into full virtual realies telling the same story, if it's any good, with smell, and taste, and touch, and pleasure-centre stimulation, within a fully realized world that can be synthesized as cheaply as theatrical sets? And to reach what demographics? A few thousand people a day when the same budget creates a hit machine tapped by scores of millions!

The theatre is dead.

But the theatre must not die. Those who do not understand why have never set foot on a stage before a live audience. I may be the last man alive who has. You have not seen those shining eyes beyond the footlights riveted on you; you have not smelled the heady aroma of an expectant live audience. Yes, I know, if there was any interest in such ancient history, you could experience it in a realie. Or so you believe.

But the magic of the theatre cannot be emulated: the intimate connection between the human actor and a live audience. For
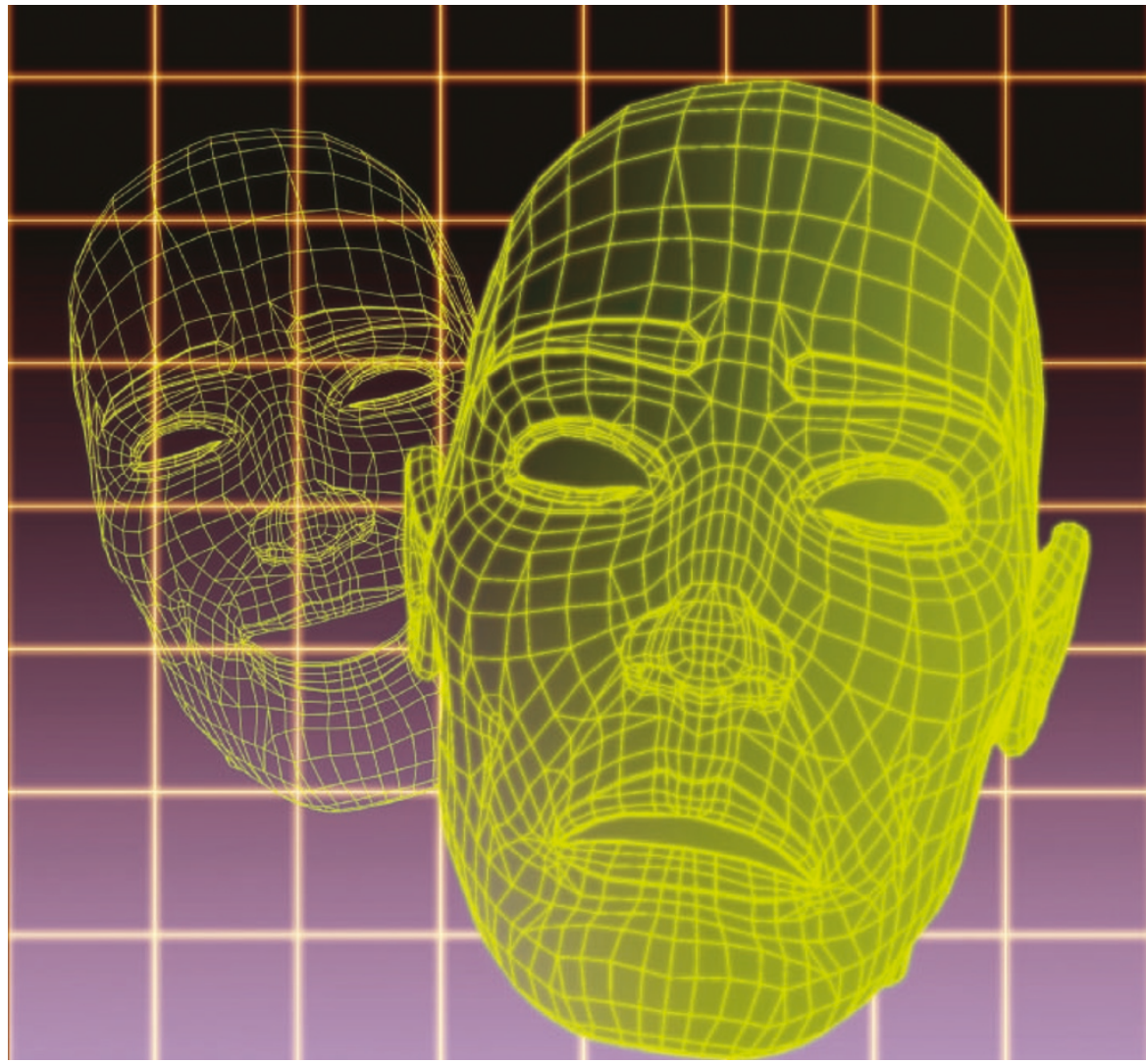

when the play succeeds, there is a collaboration between the actors and the audience the actors and the audience live and breathe together, a community of the spirit in which the reaction of the audience influences the actors and shapes the live audience's experience itself. A positive feedback loop, as you moderns would so unromantically have it.

If the popular 'entertainments' that fill so many broadcast hours are all soulless exercises, with none of the drama acted out by fellow humans in the intimacy of a living community, life itself will be entirely reduced to virtuality. Has it not already happened in the retirement heavens, where zombies are tapped into a thousand available channels of realies, 24 hours a day? The life-support technology already exists and it only awaits a profitable business model for the entire population of the planet to dream their lives away as the solipsistic gods of their perpetual virtual heavens.

This is neither drama nor life. This is tyranny with an entertaining face. If the theatre dies, so dies the human spirit. For only a great act of theatre can reawaken it.

Antonin Artaud wrote of the Theatre of Cruelty: do not amuse your audience. Be cruel to your audience in order to seize and hold it. I shall go him one further.
The King will be parading from Buckingham Palace to the Houses of Parliament in his magnificently baroque horse-drawn carriage and in full costume, like the penultimate actor that he is, his simple performance witnessed live by throngs gathered along the way to experience the Royal Presence at first hand.

I shall wear the costume I wore when I played Othello the Moor, which no doubt will be taken for that of a Caliphate terrorist, and the sword I shall use will be a scimitar, which I shall plunge into the Royal breast before I detonate the explosives under my robes. It should bring on the long-awaited war. Thus will I remind the world of the sovereign power of an act of live theatre.

And my last line on the stage will be that declaimed in like manner by a scion of a noble theatrical family whose name yet lives for the ages. Not that of the great Edwin but that of his otherwise mediocre brother. John Wilkes Booth.

\section{"Sic semper tyrannus!"}

Norman Spinrad's latest novel, Mexica, will be published by Little Brown in November 2005. He is a novelist, screenwriter, critic and essayist. He writes the occasional song, paints the occasional painting, and does the very occasional turn as rock star. He is currently bouncing back and forth between Paris and New York. 